\title{
CHEMICAL ANALYSIS OF ORDINARY PORTLAND CEMENT OF JORDAN
}

\author{
Falah F Bani Hani \\ Al-Huson University College, Al-Balqa Applied University, Jordan \\ Chem. Eng. Dept. P.O. Box 50, AlHuson 21510 Jordan \\ dr.falahf@yahoo.com
}

\begin{abstract}
:
This study compares the quality of different brands of ordinary Portland cement (OPC) available in Jordan. The amounts of chemical constituents such as Silica $\mathrm{SiO} 2, \mathrm{Al}_{2} \mathrm{O}_{3}, \mathrm{CaO}, \mathrm{MgO}$,Sulfuric anhydride $\left(\mathrm{SO}_{3}\right)$ were determined in accordance with British Standard (BS) specifications. All the results are presented to provide both quantitative and qualitative notion that several locally produced ordinary compositions of most of these constituents as determined experimentally were within the range of the standard values. The possible reasons for variation in chemical compositions and their consequences have been discussed.
\end{abstract}

\section{INTRODUCTION:}

Cement industry is considered a strategic industry, because it is directly related to the work of construction and reconstruction. It uses hydraulic cement as the association of mortar or concrete components. This industry is simple compared to the major industries, and depend on the availability of raw materials necessary to do so. There are five cement plants in Jordan :Alrajihi cement, Ashamalia cement, Arabia cement company, La farge Gpoup has two cement plants, one in Fuheis (Fuhese cement) and the other in Ashaedia (Ashaedia cement).
All these cement plants produce Ordinary Portland cement (OPC).

The basic raw materials in cement industry consist mostly of the clay and limestone, which are heated at a temperature sufficient to cause a reaction between them for the production of calcium silicate $^{[1,2]}$.

The cement to be used in construction must have certain qualities in order to play its part effectively in structure. When these properties lie within a certain specified range of standard values, the engineer is confident that in most of the cases the cement performance will be satisfactory. In addition, based on these 
properties it is possible to compare the quality of cement from different sources. A number of tests are performed in the laboratories of cement industries to ensure that the cement is of the desired quality and it conforms to the requirement of the relevant standards.

There are several brands of OPC available in market but their chemical compositions are the same. Variations in physical properties occur due to the variation in the amount of chemical constituents. This study aims to conduct a chemical analysis of OPC. Chemical constituents of silica $\left(\mathrm{SiO}_{2}\right.$, Aluminum oxide $\left(\mathrm{Al}_{2} \mathrm{O}_{3}\right)$, Iron oxide $\left(\mathrm{Fe}_{2} \mathrm{O}_{3}\right)$, lime content, magnesium oxide (MgO), sulfuric unhydride $\left(\mathrm{SO}_{3}\right)$, insoluble residue (IR), free lime and lost on ignition (LOI) are determined and compared with British Standars Specification ${ }^{[1,3]}$.

\section{BASIC CHEMISTRAY OF PORTLAND CEMENT:}

During calcination the volume contracts and during hydration it swells. Two possible reactions take place.

Calcinations: $\mathrm{CaCO}_{3}(\mathrm{~s})=\mathrm{CaO}(\mathrm{s})+\mathrm{CO}_{2}(\mathrm{~g})$

Hydration: $\mathrm{CaO}(\mathrm{s})+\mathrm{H}_{2} \mathrm{O}(1)=\mathrm{Ca}(\mathrm{OH})_{2}(\mathrm{~s})$

The raw materials used in the manufacture of portland cement consist mainly of lime, silica, alumina and iron oxide. These compounds interact with one another in the kiln to form a series of more complex products, and apart from a small residue of uncombined lime, which has not had sufficient time to react; a state of chemical equilibrium is reached.
Chemical components in portland cement are combined to different potential compounds form. The amounts of these potential compounds are responsible for various physical properties of portland cement.

Four major compounds in portland cement are $\mathrm{C}_{2} \mathrm{~S}, \mathrm{C}_{3} \mathrm{~S}, \mathrm{C}_{3} \mathrm{~A}$, and $\mathrm{C}_{4} \mathrm{AF}$. The silicates, $\mathrm{C}_{3} \mathrm{~S}$ and $\mathrm{C}_{2} \mathrm{~S}$, are the most important compounds, which are responsible for the strength of hydrated cement paste. The presence of $\mathrm{C}_{3} \mathrm{~A}$ in cement is undesirable. $\mathrm{C}_{4} \mathrm{AF}$ is also present in cement in small quantities, and, compared with the other it does not affect the behaviour of the cement significantly ${ }^{[3,4]}$. It should be noted that The $\mathrm{C}$ stands for $\mathrm{CaO}$, The A stands for $\mathrm{Al}_{2} \mathrm{O}_{3}$, The $\mathrm{S}$ stands for $\mathrm{SiO}_{2}$, The $\mathrm{F}$ stands for $\mathrm{Fe}_{2} \mathrm{O}_{3}$.

\section{EXPERIMENTAL PART:}

The testing procedures based on British Standard have been followed for chemical analysis of prorland cement. Amount of total $\mathrm{SiO}_{2}, \mathrm{Al}_{2} \mathrm{O}_{3}, \mathrm{Fe}_{2} \mathrm{O}_{3}$, lime content, $\mathrm{MgO}, \mathrm{SO}_{3}, \mathrm{IR}$, free lime and LOI were determined ${ }^{[3-6]}$.

\section{RESULITS AND DISCUSSION:}

Different calculated data have been taken for different parameters during the laboratory work. Table 1 is a summarized form of various test results. For better comparison these are presented graphically.

British standards specify amounts of $\mathrm{SiO}_{2}$ in portland cement is $21 \%$. It has been observed that Rashadiah, Fuheis and Ashamalia cements are within specified limit. But Rajihi, and Arabia cements slightly deviate from the 
specification. Figure 1 shows the amount of $\mathrm{SiO}_{2}$

in different brands of cement.

Table 1 : Amount of chemical constituents in portalnd cement OPC samples (\%)

\begin{tabular}{||l|c|c|c|c|c|c||}
\hline $\begin{array}{c}\text { Constituent } \\
(\%)\end{array}$ & $\begin{array}{c}\text { BS for } \\
\text { OPC }\end{array}$ & $\begin{array}{c}\text { Rashediah } \\
\text { (L-RC) }\end{array}$ & $\begin{array}{c}\text { Fuheis } \\
\text { (L-FC) }\end{array}$ & $\begin{array}{c}\text { Arajihi } \\
\text { (ARC) }\end{array}$ & $\begin{array}{c}\text { Ashmalia } \\
\text { (AsC) }\end{array}$ & $\begin{array}{c}\text { Arabia } \\
\text { (ACC) }\end{array}$ \\
\hline $\mathrm{SiO}_{2}$ & 21.0 & 22.20 & 21.41 & 22.13 & 21.32 & 21.25 \\
$\mathrm{CaO}$ & 65.0 & 65.56 & 64 & 63.63 & 65.02 & 64.32 \\
$\mathrm{MgO}$ & 0.70 & 1.44 & 1.83 & 1.91 & 1.26 & 1.20 \\
$\mathrm{Free} \mathrm{lime}$ & 2.00 & 1.11 & 1.15 & 1.08 & 1.28 & 1.21 \\
$\mathrm{Al}_{2} \mathrm{O}_{3}$ & 6.00 & 3.69 & 5.05 & 5.22 & 4.62 & 4.22 \\
$\mathrm{Fe}_{2} \mathrm{O}_{3}$ & 3.50 & 3.33 & 3.51 & 3.33 & 3.40 & 3.32 \\
$\mathrm{SO}_{3}$ & 1.50 & 0.90 & 1.77 & 2.40 & 2.66 & 3.46 \\
$\mathrm{IR}$ & 1.50 & 0.65 & 0.55 & 0.50 & 0.40 & 0.35 \\
$\mathrm{LOI}$ & 4.00 & 1.36 & 1.79 & 1.48 & 1.30 & 1.98 \\
\hline \hline
\end{tabular}

Figure 1: Variation of $\mathrm{SiO}_{2}$

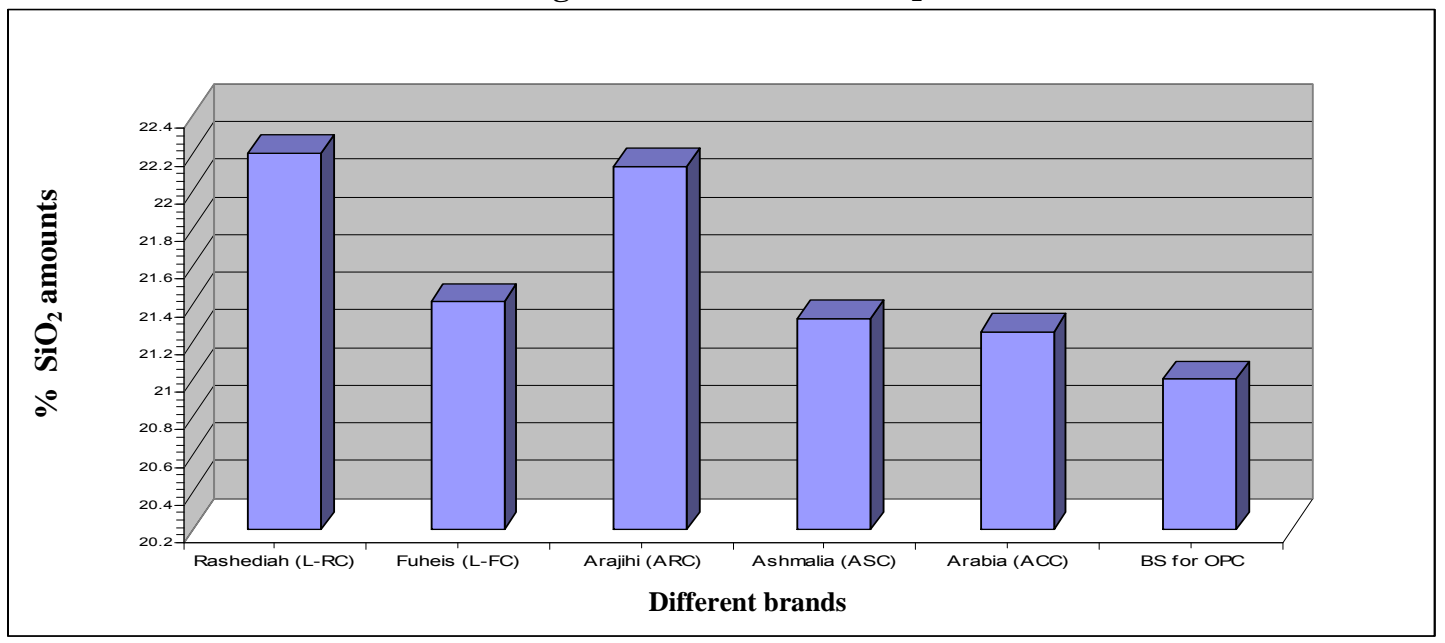

Figure 2: Variation of $\mathrm{Al}_{2} \mathrm{O}_{3}$ 


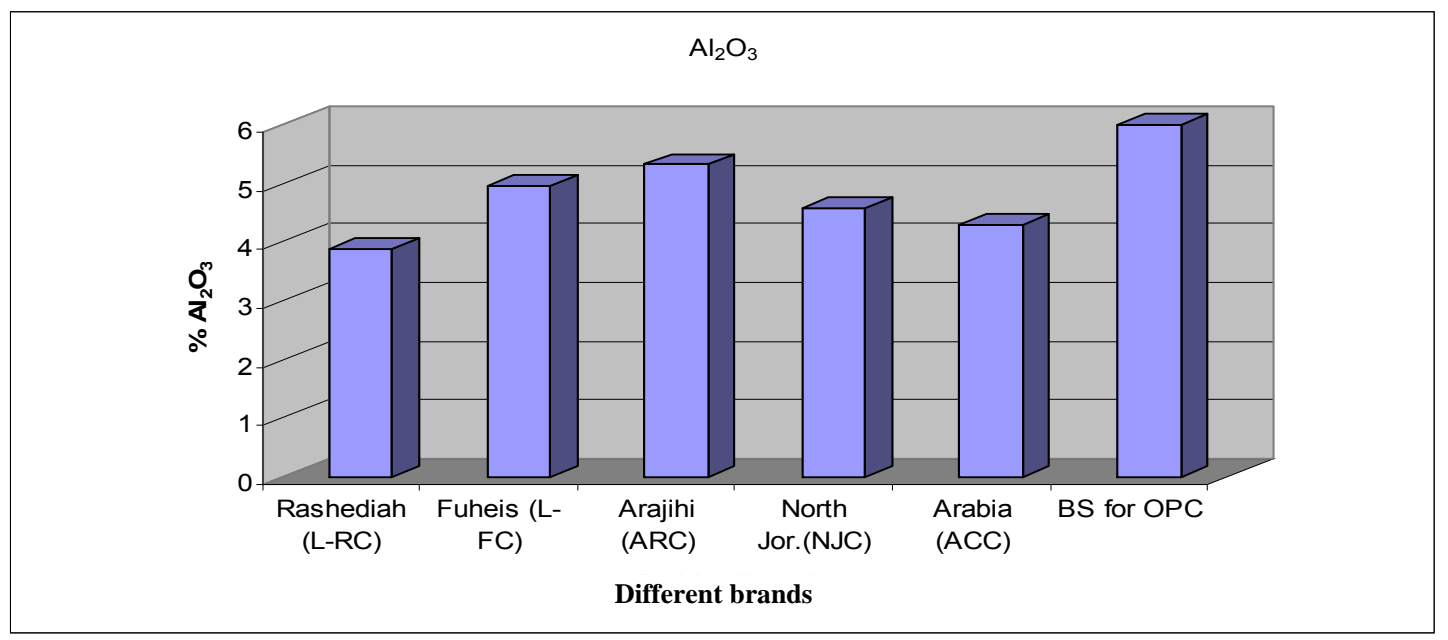

Figure 3: Variation of $\mathrm{Fe}_{2} \mathrm{O}_{3}$

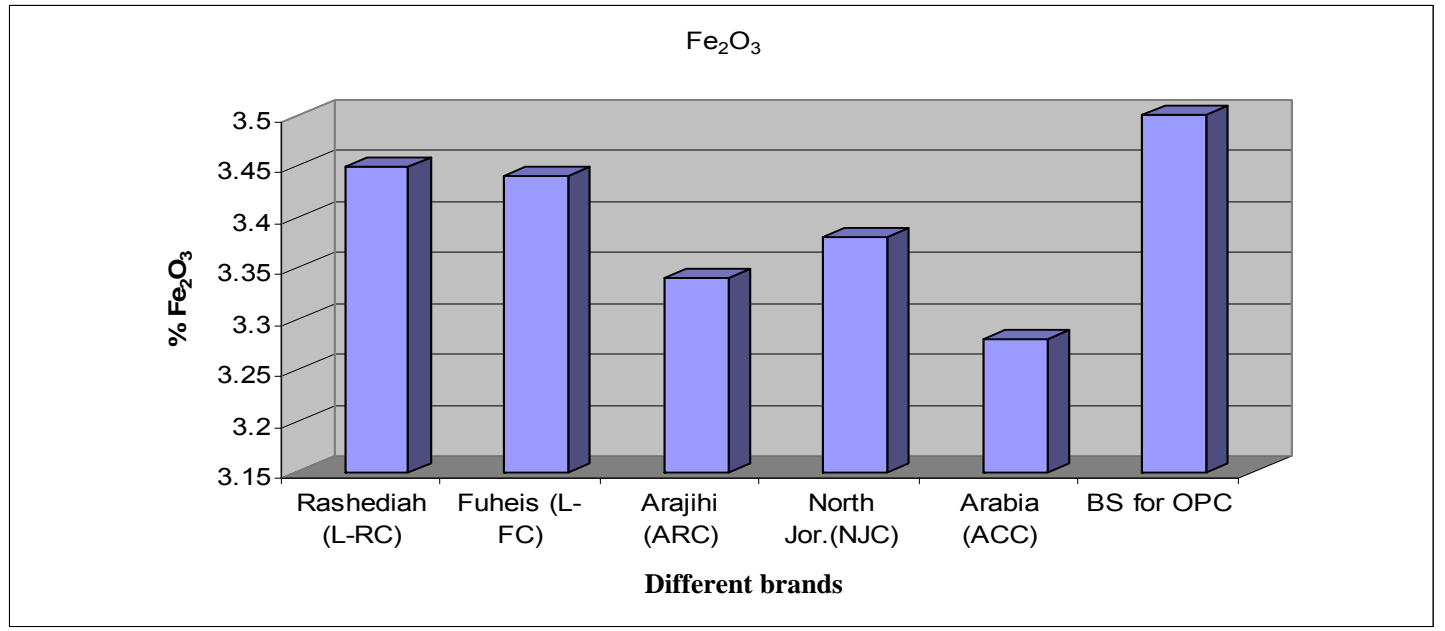

Figure 4: Variation of $\mathrm{CaO}$

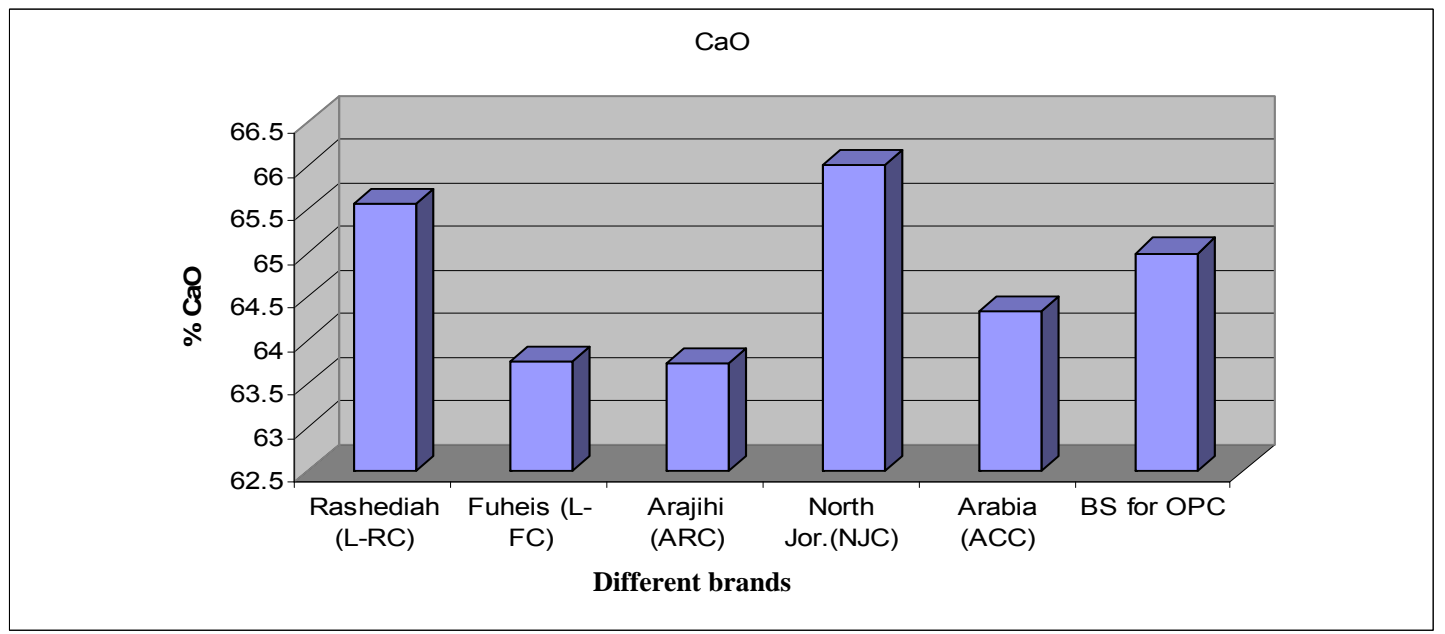


Figure 5: Variation of MgO

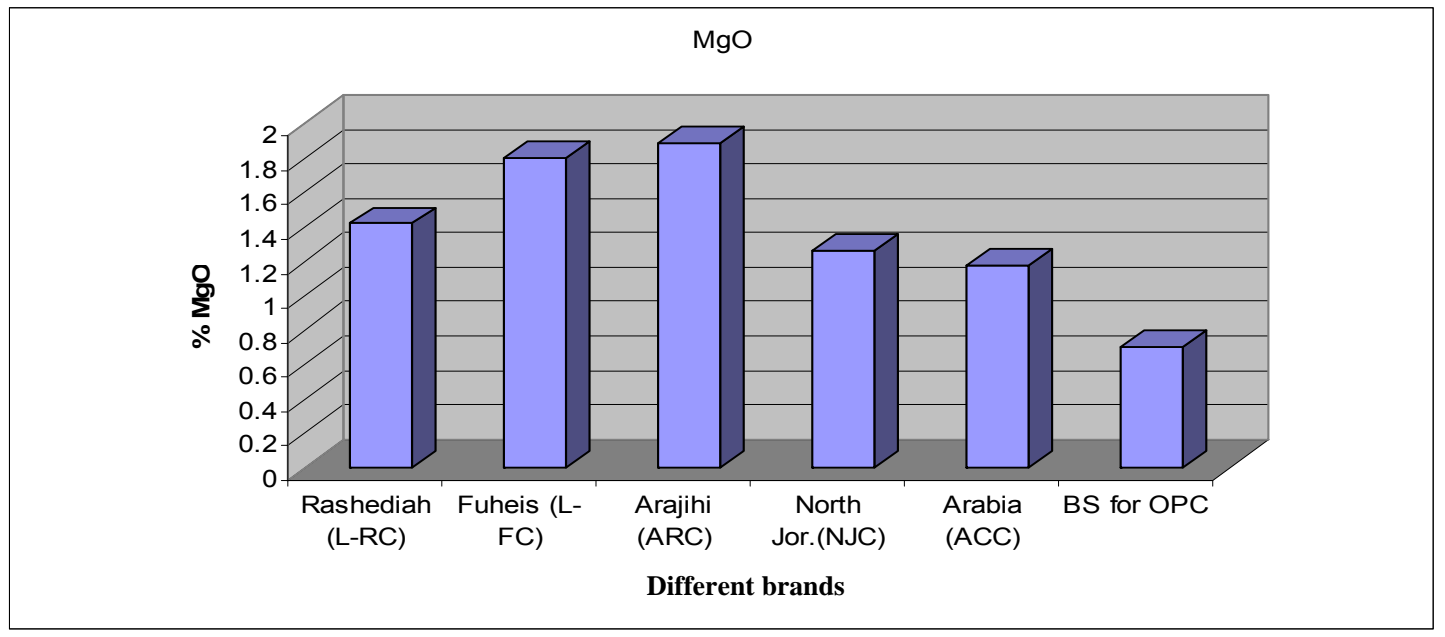


Figure 6: Variation of Free Lime

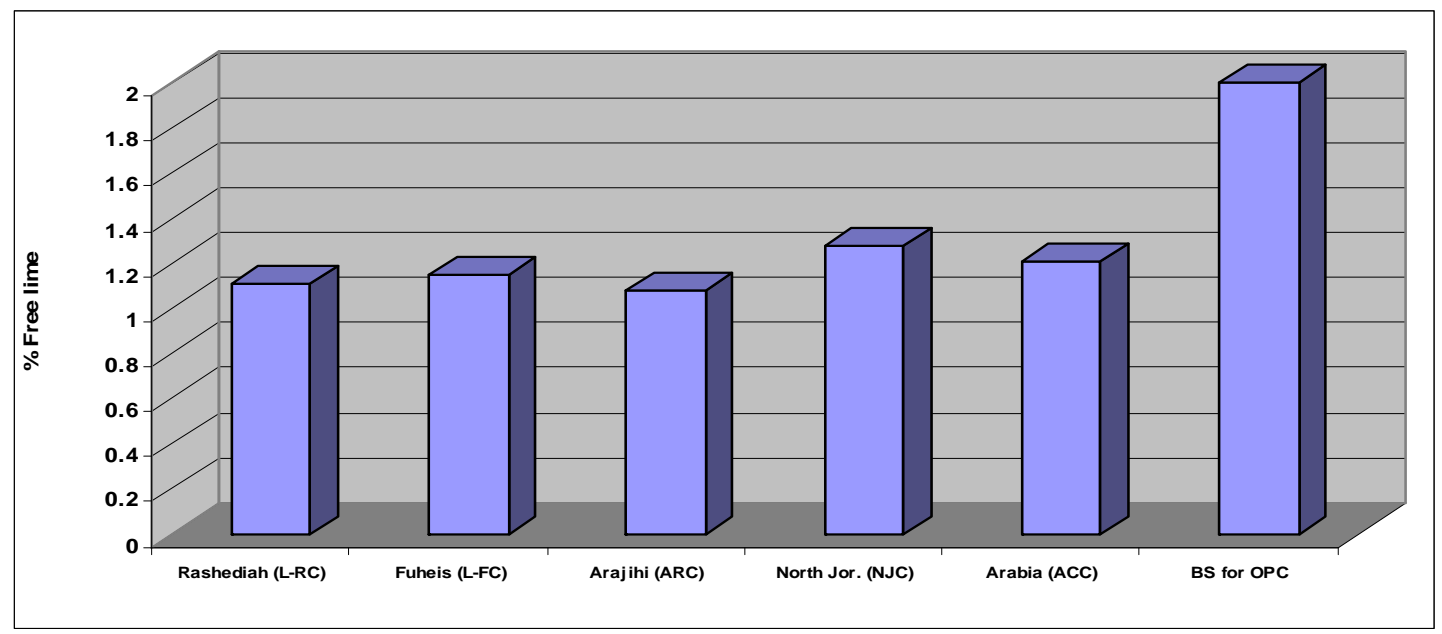

Figure 7: Variation of $\mathrm{SO}_{3}$

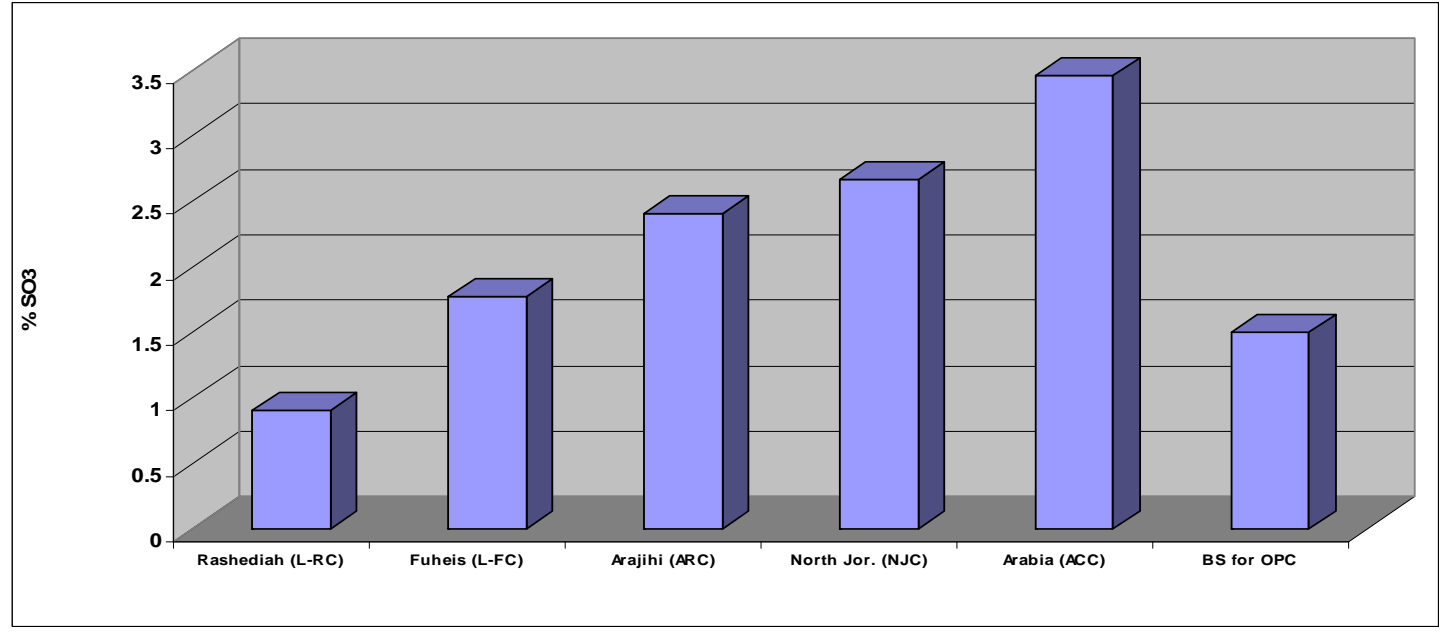

Figure 8: Variation of IR

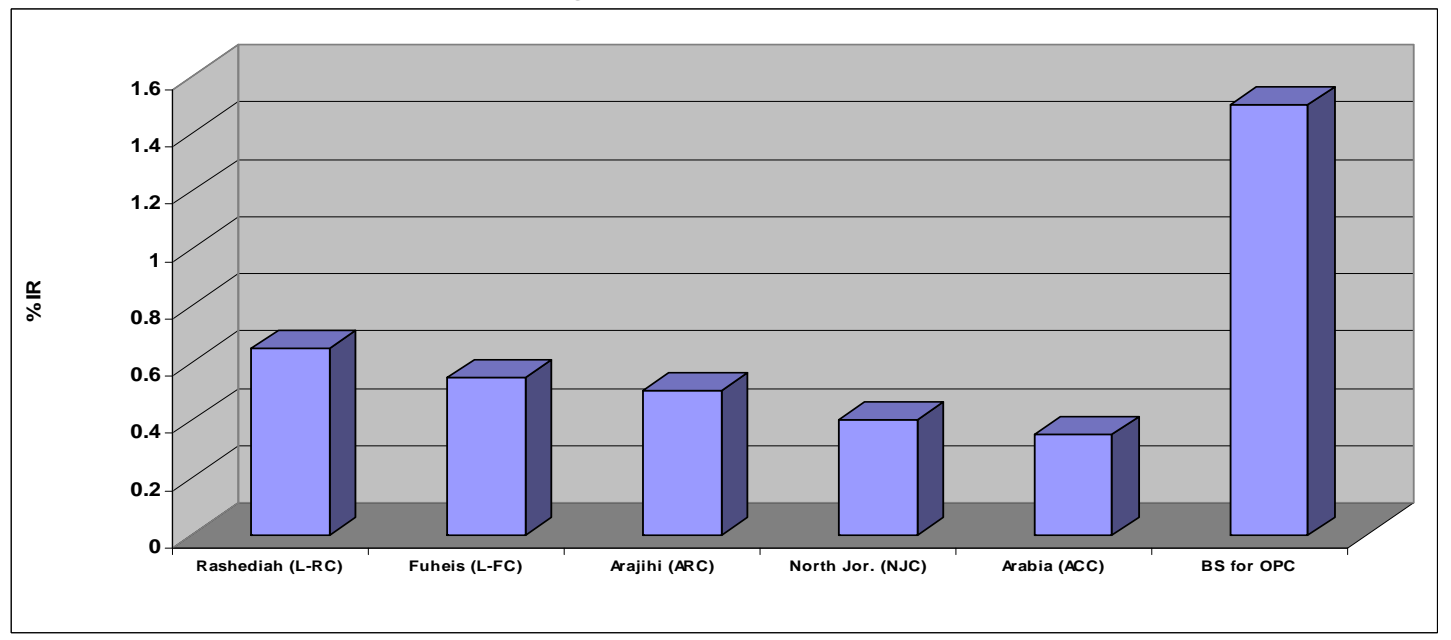

Different brands 
Amount of $\mathrm{CaO}$ as specified by the British standards should be within the range $63 \%$ to $66 \%$. All five brands of cement contain $\mathrm{CaO}$ within the specified limit that can be observed from Figure 2.

The proper lime content is limited due to the lower early strength produced when lime content of OPC is too low, and unsoundness when it is too high. High lime content is associated with early strength whereas, slightly lower content of lime favours ultimate strength which develops gradually over a long period of time. In order to increase the strength it is necessary to raise the lime content, or grind finer, or both. But higher temperatures are required to burn the high lime mixtures ${ }^{[8]}$.

British standards specify amounts of MgO in OPC not more than $2.0 \%$. It was found that all the cement samples were within the specified limit Figure 3.

The magnesia content is limited by the standard specifications not to exceed $2 \%$ because higher magnesia contents may be detrimental to the soundness of the cement, especially at late ages. Beyond that limit it appears in the clinker as free MgO (periclase). Pericalse reacts with water to form $\mathrm{Mg}(\mathrm{OH})_{2}$, and this is the slowest reaction among all other hardening reactions. Since $\mathrm{Mg}(\mathrm{OH})_{2}$ occupies a larger volume than the $\mathrm{MgO}$ and is formed on the same spot where the pericalse particle in located, it can split apart the binding of the hardened cement paste, resulting in expansion cracks commonly known as magnesia expansion $^{[3,7]}$.
There is not advantage in adding extra lime unless it is brought into combination with other constituents. If appreciable lime is left uncombined, it may cause expansion and cracking of the mortar or concrete ${ }^{[7]}$. Amount of free lime were found to vary in between 1.110 to 1.279 \& among the different brands of cements that is shown in Figure 4.

It was found that amount of $\mathrm{Al}_{2} \mathrm{O}_{3}$ in Rajihi cement was within the specified limit. But Reshadiah, Fuheis, Arabia and Ashamalia cement were slightly below the specified limit. On the other hand, amount of $\mathrm{Fe}_{2} \mathrm{O}_{3}$ was found within the specified range. Variations of $\mathrm{Al}_{2} \mathrm{O}_{3}$ and $\mathrm{Fe}_{2} \mathrm{O}_{3}$ are shown in Figure 5 and 6 respectively.

If the lime content is fixed, and the silica becomes too high, which may be accompanied by a decrease in alumina and ferric oxide, the temperature of burning will be raised and the special influence of the high lime will be lost. If the lime content is too low, which means an increase in the alumina and ferric oxide, the cement may become quick-setting and contain a larger amount of alumina compounds, which appear to be of little value for their cementing qualities. Rapid setting is undesirable, and is not permitted by the standard specifications, because the cement sets up so rapidly that it cannot properly be worked in the forms before stiffening occurs ${ }^{[3,8]}$.

Brithish standards specify maximum amounts of $\mathrm{SO}_{3}$ in portland cement be $1.5 \%$ Rashadiah, Fuheis, and Rajehi cements were found to contain excess amount of $\mathrm{SO}_{3}$ where as 
Ashamalia cement slightly deviated from the specification Figure 7.

To control setting time effectively, cement needs a minimum amount of calcium sulfate, mostly in the form of gypsum added to the clinker.

On the other hand, the maximum allowable $\mathrm{SO}_{3^{-}}$content in the cement to prevent sulfate expansion, is established according to the various cement standards, between $1.5-2.7 \%$ $\mathrm{SO}_{3}$. At the lowest limit imposed by cement standard specification, it could be possible that there is no sufficient scope, left for an extensive sulfatizing of the alkalies ${ }^{[9,10]}$.

Insoluble residue (IR) is a non-cementing material, which eventually exists in portaland cement. This residue material affects the properties of cement, especially its compressive strength. To control the non-cementing material in portalnd cement, Brithish standard allows the IR content to a maximum limit of $1.5 \%$. Figure 8 shows that all the cement samples were within this limit.

Addition of the IR in Portland cement affect the compressive strength of cement mortar during the early age, but it is reduced as the cement mortar getting older.

A high Loss on ignition (LOI) indicates prehydration and carbonation, which may be caused by improper and prolonged storage or adulteration of OPC during transport or transfer. All the cement samples were found to be competent with regard to maximum LOI limit of $4.0 \%$ as specified by the British Standard.
The possible reasons of variations are specification of raw mix, non-uniformity of mixture, and impurities from various stages of processing, and intentional alteration.

Variations in chemical constituents affect the cement properties like, hardening/ hydration, setting time, corrosion resistance, color, etc ${ }^{[9,10]}$.

Possible and potential sources of error in testing might be grade of chemicals, and preparation of reagents, and accuracy of titrametric method (Classical analytical method) which depends on the technical experience of the investigator. Maximum temperature range of the furnace was $800^{\circ} \mathrm{C}$. But sometimes it was necessary to raise temperature up to $1000^{\circ} \mathrm{C}^{[6-8]}$.

\section{CONCLUSION:}

The ideal composition range of protalnd cement is the problem of the research chemist and engineers. But out of the experience of observant operatives and the formulation of experimentally demonstrated principles by engineers and chemists, there have been established certain rather definite limitations in the feasible composition of a cement. Within those limits experience has shown that the mixture behaves satisfactorily in the kilns and produces good cement; outside of those limits experience has shown that trouble in burning may result or that the cement maybe of inferior quality. 


\section{REFERENCES:}

1-Iffet Yakar Elbeyli, Emek Möröydor Derun, Thermal analysis of borogypsum and its effects on the physical properties of Portland cement, Cem. Concr. Res., 2003. 33(11): PP. 1729-1735.

2-S. Ali, I. A. Khan and M. I. Hossain, Chemical Analysis of Ordinary Portland Cement of Bangladesh, Chemical Engineering Research Bulletin, 2008, 12 PP: 7-10.

3-British standard Institutes, Section BS 4550:

Part 2: 1970 and BS 12: 1991.

4-Taylor H.F. W., The Chemistry of Cements. Vol. 1. 1946, New York: Academic Press.

5-Furman N.H., et al., Standard Method of Chemical Analysis, $6^{\text {th }}$ ed. 1962, New York: Van Nostrand Reinhold Co.

6-Amin N., Ali K. and Shah M., Raw mix designing, clinkerization and manufacturing of high strength Portland cement from the lime stone and clay of Darukhula Nizampur, District Nowshera, N.W.F.P., Pakistan, Chinese journal of geochemistry, 2009. 28(3): PP. 279-283.

7-Neville A.M., Concrete Technology, $4^{\text {th }}$ ed. 1996, Singapore: Long man Singapore Publishers Ltd.

8-Pandey G.N. and S. D. Shukla, A Text Book of Chemical Technology. Vol. 1. 1980, New Delhi: Vikas Publishing House.

9-J. Bensted, Early hydration behaviour of portland cements containing boro-, citro- and desulphogypsum. Cem. Concr. Res. 1980, 10, P. 165.

10-Noor-ul-Amin, Khurshid Ali, Chemical Analysis and Comparison of Ordinary Portland Cement of Pakestan, Chemical Engineering Research Bulletin, 2010, 14, PP. 45-49.

$$
\begin{aligned}
& \text { التحليل الكيماوي للأسمنت الأردني البورتلاندي العادي } \\
& \text { فلاح فهد بني هاني } \\
& \text { كلية الحصن - جامعة البلقاء التطبيقية - الأردن }
\end{aligned}
$$

$$
\begin{aligned}
& \text { هـذه الدراسـة تقـارن جـودة الأســتت البورتلانـدي العـادي الـذي ينـتج مسن قبـل شـركات مختلفـة في الأردن، }
\end{aligned}
$$

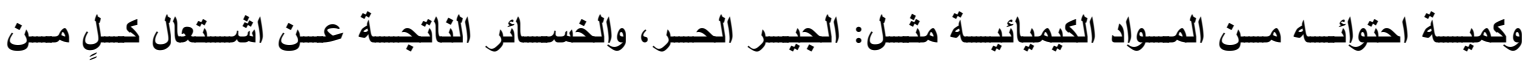

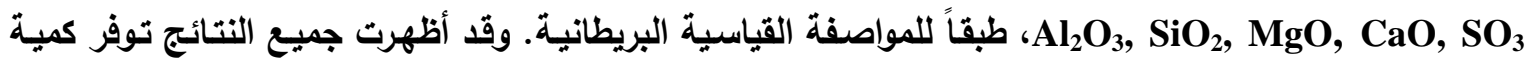

$$
\begin{aligned}
& \text { المكونات للمنتجات المختلفة، والتراكيب العادية لمعظم هذه المكونـات المحددة سـابقاً في الإطار العملي من خلال } \\
& \text { حزمة المواصفات القياسية، وكذلك تمت مناقشة الأسباب المحتملة للاختلاف في التركيب الكيماوي، وما يترتب على } \\
& \text { ذلك من مخاطر. }
\end{aligned}
$$

